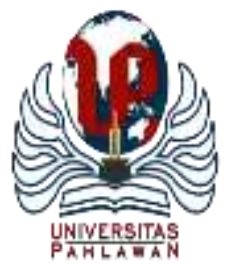

Edukatif : Jurnal Ilmu Pendidikan Volume 3 Nomor 6 Tahun 2021 Halm 4363 - 4373

EDUKATIF: JURNAL ILMU PENDIDIKAN

Research \& Learning in Education

https://edukatif.org/index.php/edukatif/index

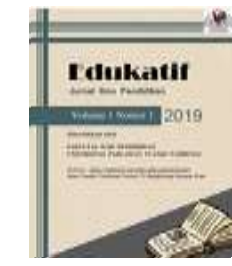

\title{
Pengembangan Media Pembelajaran Word Search Puzzle Berbasis Android pada Mata Pelajaran Ekonomi Kelas X pada Saat Pandemi Covid-19
}

\author{
Pandu Wahyu Gelang Pamungkas ${ }^{1 凶}$, Muhammad Abdul Ghofur ${ }^{2}$ \\ Universitas Negeri Surabaya ${ }^{1,2}$ \\ E-mail : pndwayu@gmail.com ${ }^{1}$, muhammadghofur@ unesa.ac.id $^{2}$
}

\begin{abstract}
Abstrak
Permasalahan pembelajaran di SMA yaitu rendahnya daya ingat siswa dalam mengingat materi diberikan oleh guru, dikarenakan peserta didik dituntut mempelajari semua mata pelajaran. Hal ini pastinya memiliki dampak pada hasil belajar siswa. Model pembelajaran menggunakan ADDIE dapat meningkatkan daya ingat siswa dalam jangka panjang. Tujuan dilakukan penelitian untuk mengetahui peningkatan daya ingat siswa menggunakan media pembelajaran puzzle. Desain penelitian ini menggunakan pretest-posstest. Subjek penelitian sebesar 36 siswa di SMA Negeri 2 Kota Mojokerto. Dapat diketahui, hasil penelitian bahwa penerapan model ADDIE berdampak positif terhadap peningkatan daya ingat siswa. Respon siswa terhadap penggunaan puzzle dalam pembelajaran siswa berpengaruh terhadap peningkatan hasil belajar siswa.
\end{abstract}

Kata Kunci: Hasil belajar, ADDIE, daya ingat, puzzle.

\section{Abstract}

The problem of learning in high school is the low memory of students in remembering the material given by the teacher, because students are required to learn all subjects. This certainly has an impact on student learning outcomes. The learning model using ADDIE can improve students' memory in the long term. The purpose of this research is to determine the improvement of students' memory using puzzle learning media. The design of this study used a pretest-posttest. The research subjects were 36 students at SMA Negeri 2 Mojokerto City. It can be seen, the results of the study that the application of the ADDIE model has a positive impact on increasing students' memory. Student responses to the use of puzzles in student learning have an effect on increasing student learning outcomes.

Keywords: Learning result, ADDIE, recall memory, puzzle.

Copyright (c) 2021 Pandu Wahyu Gelang Pamungkas, Muhammad Abdul Ghofur

$\triangle$ Corresponding author

Email : pndwayu@gmail.com

DOI : https://doi.org/10.31004/edukatif.v3i6.1464 
4364 Pengembangan Media Pembelajaran Word Search Puzzle Berbasis Android pada Mata Pelajaran Ekonomi Kelas X pada Saat Pandemi Covid-19 - Pandu Wahyu Gelang Pamungkas, Muhammad Abdul Ghofur DOI: https://doi.org/10.31004/edukatif.v3i6.1464

\section{PENDAHULUAN}

Dunia pendidikan merupakan usaha melakukan pembelajaran secara terencana dengan tujuan siswa memiliki memori pembelajaran dan menjadikan siswa dapat berkontribusi kepada masyarakat (Raharjo, 2010). Pendidikan berhubungan dengan dengan proses pembelajaran, oleh sebab itu diperlukan peran pendidik atau guru. Peran pendik Menurut Pullas dan Young (dalam Azhar, 2013) diantaranya: mendidik, pembimbing, penasihat, innovator dan utamanya sebagai pengajar. Pendidik bertugas sebagai pengajar dan menyampaikan informasi kepada siswa. Salah satu cara menyampaikan informasi dengan melalui perantara yang disebut media pembelajaran.

Dunia pendidikan dengan adanya pandemi Covid-19 harus melakukan penyesuaian pembelajaran tidak melakukan tatap muka langsung, yakni online study. Pembelajaran yang dilakukan melalui online membawa konsekuensi pembelajaran tidak dapat dilakukan secara bertatap muka. Hal ini menjadi tantangan bagi para pendidik dalam memberikan pengajaran kepada siswanya. Bagi seorang guru tidak dapat melakukan kewajibannya apabila tidak memiliki kompetensi memberikan metode mengajar yang telah disusun oleh ahli pendidikan (Bahri, 2013). Seorang guru dituntut memiliki metode dalam proses pembelajaran, dengan tujuan supaya peserta didik dapat belajar secara efektif dan memenuhi target dari hasil belajar.

Hasil belajar merupakan kecakapan atau pengetahuan didapatkan oleh siswa setelah melakukan pembelajaran. Menurut penjelasan Sudjana,(2011) hasil belajar memiliki tiga aspek diantaranya yakni aspek kognitif, aspek afektif dan aspek psikomotor. Aspek hasil belajar kognitif dapat diartikan siswa dapat menyerap materi yang diajarkan oleh guru. Sedangkan aspek efektif lebih memfokuskan kepada pembentukan karakter dari pembelajaran yang dilakukan. Sedangkan aspek psikomotor lebih berfokus dapat dipengaruhi oleh factor interna dan ekstern. Factor internal meliputi jasmani,rohani dan psikologis. Sementara itu, faktor ekstern yang meluputi lingkungan disekitarnya baik keluarga,teman ataupun masyarkat. Sementara itu hasil belajar memiliki 2 dasar teori yang dipakai teori behavioristik dan konstruktivisme.

Teori behavioristik yang dikemukakan oleh Gage dan Berliner berkaitan dengan pengalaman yang dapat membentuk perubahan tingkah laku. Sedangkan gagasan kontruktivisme merupakan pendekatan yang mengajak siswa untuk berfikir memecahkan suatu permasalahan secara bersama. Prinsip utama pembelajaran kontrutivisme yakni pengetahuan tidak diperoleh secara namun dapat diperoleh secara langsung dari struktuf dan fungsi konigtif secara adaptif berdasarkan pengalaman nyata (Ivana Rahman, 2011).

Keberhasilan dan kualitas juga dipengaruhi oleh kualitas pembelajaran. Penerapan media pembelajaran inovatif dapat meningkatkan daya ingat siswa untuk mengingat materi pembelajaran dalam jangka panjang. Dengan kondisi seperti ini serta berkembangnya teknologi dapat membuat media pembelajaran yang membuat siswa dapat memahami pelajaran yang diajarkan. Kebanyakan siswa pada masa sekarang tidak menyukai pembelajaran yang konvensional karena dianggap sulit dimengerti dan membosankan (Wahono dalam Luhsasi \& Sadjiarto, 2017).

Pendidikan dari tingkat dasar hingga perguruan tinggi terdampak dengan adanya wabah ini. Tidak terkecuali dengan yang terjadi di Sekolah SMA Negeri 2 Kota Mojokerto. Para siswa dapat mengikuti pembelajaran dengan guru secara daring online. Penelitian ini dilakukan pada siswa kelas X SMA Negeri 2 Kota Mojokerto Jurusan Ilmu Pengetahuan Sosial (IPS) pada pembelajaran ekonomi.

Pada saat observasi dan wawancara pada ekonomi Ibu Tri Winarsih ditemukan sebuah temuan permasalahan bahwa siswa kesulitan dalam mengingat pada materi pembelajaran bank sentral, sistem pembayaran dan alat pembayaran. Hal ini dikarenakan media pembelajaran yang diberikan oleh guru berupa modul/persentasi yang diberikan guru dalam bentuk powerpoint kurang dapat diingat oleh siswa. Berdasarkan hal tersebut, dibutuhkan media pembelajaran yang efektif, dengan tujuan siswa dapat menerima materi yang sudah diberikan oleh guru dan memenuhi target hasil belajar. 
Berdasarkan permasalahan diatas, dapat menggunakan hasil belajar dengan dasar kontruktivisme dengan model pembelajaran secara kognitif. Model pembelajaran ini dimana guru menghadirkan informasi yang dilakukan melalui aksi secara aktif dari siswa untuk mengamti, mendengarkan dan menggunakan bahan belacar cetak maupun elektronik. Aktivitas pembelajaran tidak bisa dilepaskan dari proses mengingat (Bahri, 2013) piaget (dalam Desmita,2009) menjabarkan tingkatan perkembangan kognitif meliputi sensori motoric, tahap pra-operasionalm tahap pra-operasional dan tahap operasional formal.

Pada dasarnya memori manusia terbagi menjadi dua yakni jangka panjang dan pendek. Memori jangka panjang yakni memori yang dapat mengingat dalam waktu yang lama seperti peristiwa yang terjadi dalam kehidupan mereka, ilmu pengetahuan dan hal yang mereka peroleh selama masa sekolah. Sedangkan Memori jangka pendek merupakan memori yang dapat mengingat dalam beberapa waktu saja lalu kesulitan mengingat kembali.

Adanya kemampuan mengingat mengindisikasikan manusia memiliki kemampuan menerima, menyimpan dan menimbulkan pengalaman yang terjadi pada dirinya (Walgito, 2004). Aktivitas seseorang dalam mengingat lagi pembelajaran yang sudah dipelajari dalam ilmu psikologi disebut recall memory. Pada dasarnya recall memory berguna pada saat evaluasi hasil belajar. Salah satu faktor keberhasilan recall memory yakni pengulangan. Menurut penelitian yang telah dilakukan Lloyd dan Peterson (dalam Solso, Maclin, \& Maclin, 2008) menjelaskan kemampuan mengingat akan berkurang ketika seseorang tidak melakukan pengulangan informasi yang tersimpan dalam short term momory.

Dalam meningkatkan daya ingat para siswa dibutuhkan media yang digunakan dalam pembelajaran. Media tersebut merupakan peralatan yang berisi tentang isi pembelajaran yang akan disampaikan (Darmayanti, 2016). Selain itu, media pembelajaran dapat dimaknai sebagai salah satu penghubung pembelajaran guru dengan siswa. Media pembelajaran dibedakan menjadi dua yakni pembelajaran konvensional dan inovatif. Salah satu media pembelajaran inovatif dapat dipakai dalam peningkatan daya ingat siswa yakni media Word Search Puzzle.

Word Search puzzle merupakan sebuah game. Banyak yang beranggapan bahwa game sangat tidak baik dan memberikan pengaruh negative, faktanya game dapat memberikan manfaat dalam pembelajaran (Vitianingsih, 2016). Game dapat memberikan pengarahan, latihan dalam, menyelesaikan suatu masalah dan melatih daya ingat (Kurniawan, Satoto, \& Kridalukmana, 2015).

Word Search Puzzle menurut Sholeh dkk (dalam Sri wahyuni 2017:18) merupakan permainan pencarian kata dalam dua kategori. Sedangkan menurut Wahyuni (2018) adalah permainan mencari kata, sejenis teka-teki yang disusun dengan menemukan jawaban secara horizontal dan vertical maupun diagonal. Word Search Puzzle pada penggunaannya digunakan untuk peningkatan daya ingat siswa.

Pada penelitian terdahulu yang telah dilakukan oleh Nikma, (2020), menunjukkan menggunakan game edukasi dapat meningkatkan daya ingat siswa. Perbedaan dengan penelitian terdahulu terdapat di subjek, media pembelajaran dan mata pelajaran yang diikuti oleh siswa. Penelitian sejenis dilakukan oleh Hidayah, (2014), tentang penggunaan permainan puzzle dapat meningkatkan daya ingat mengingat meteri pembelajaran sejarah kelas XI IPA MAN Kota Kediri. Perbedaan dengan penelitian terdahulu terdapat di subjek dan mata pelajaran yang diikuti oleh siswa.

Pada penelitian yang dilakukan oleh Nurhalifah, Lestari, \& Yusuf, (2020) tentang efektivitas media pembelajaran Word Search Puzzle dalam meningkatkan daya ingat siswa pada materi ekosistem kelas VII di SMP Muhammadiyah Kupang Tahun ajaran 20218/2019, dapat diketahui bahwa tingkat kesuksesan media pembelajaran Word Search Puzzle yang dipakai didalam media pembelajaran berdampak pada peningkatan daya ingat siswa dalam memahami materi ekosistem. Perbedaan dengan penelitian terdahulu terdapat di subjek dan mata pelajaran yang diikuti oleh siswa. Selain itu, penelitian yang telah dilakukan Mujaiyanah, (2020) tentang game puzzle sebagai assessment siswa dapat meningkatkan hasil belajar siswa pada kelas X SMA LabSchool Unesa. Pada dasarnya memainkan permainan puzzle menjadikan otak terasah dan 
meningkatkan kemampuan memori seseorang sehingga berdampak pada prestasi belajar siswa. Perbedaan penelitian yang dilakukan dengan penelitian sebelumnya terdapat di subjek dan penggunaan media pembelajaran Word Search Puzzle sebagai asesmen penilaian siswa.

Berdasarkan uraian permasalahan tersebut dapat untuk dilakukan penelitian oleh peneliti "Pengembangan Media Pembelajaran Word Search Puzzle pada Mata Pelajaran Ekonomi saat Era Pandemi Covid-19. "Studi Pada Siswa X IPS SMA Negeri 2 Kota Mojokerto". Tujuan dari adanya penelitian ini yakni pengembangan media pembelajaran dalam meningkatkan mutu pembelajaran ekonomi pada kelas tersebut dan upaya adanya peningkatan daya ingat siswa dari pelajaran yang diberikan oleh guru.

\section{METODE PENELITIAN}

Penelitian ini termasuk penelitian pengembangan atau Research and Development (R\&D). Metode ini memiliki tujuan dalam menghasilkan produk dan menilai tingkat kelayakan produk tersebut. Model pengembangan media pembelajaran dilakukan menggunakan ADDIE (Analysis, Design, Development and Implementation, Evaluation) yang dikembangkan dari Dick and Carry (Sani, 2018). Penelitian ini dilakukan pada siswa SMA Negeri 2 Kota Mojokerto. Waktu penelitian dilakukan di bulan Mei 2021. Subjek dalam penelitian yakni siswa kelas X IPS SMA Negeri 2 Kota Mojokerto terdiri dari 36 siswa meliputi 12 siswa lakilaki, dan 24 siswa perempuan.

Dalam penelitian ini memakai One Group Pretest - Posttest Design yakni desain penelitian yang akan diberikan pretest dan posttest sesudah dilakukan aktivitas pembelajaran untuk dapat melihat tingkat perbedaan sebelum dan sesudah menggunakan media puzzle dengan model ADDIE. Instrumen yang digunakan dalam mengumpulkan data yakni dengan memberikan kuisioner pada siswa. Kuisioner digunakan untuk melihat respon siswa sesudah aktivitas pembelajaran. Kuisioner diuji coba kepada siswa, yakni menggunakan uji validitas dan reliabilitas. Uji validitas bertujuan untuk menilai isi instrumen yang sepadan dengan data yang akan dinilai menurut Sugiyono, (2017) uji validitas melihat nilai product moment, sedangkan uji reliabilitas melihat nilai Cornbach's Alpha.

Teknik analisis data dipergunakan dalam menganalisis data uji instrumen soal, hasil data penelitian, dan respon siswa berkaitan penggunaan media. Untuk melihat adanya peningkatan daya ingat dan hasil belajar siswa, maka dapat dilakukan dengan Uji Normalitas, Uji T, dan pre-test-posttest. Uji Normalitas dilakukan untuk dapat mengetahui data tersebut terdistribusi normal atau sebaliknya. Uji $\mathrm{T}$ dilakukan untuk dapat mengetahui apakah terdapat perbandingan signifikan untuk hasil pretest dan posttest. Adapun uji pretestposttest digunakan dalam mengukur kefektifan media pembelajaran. Berikut ini merupakan model pretestposttest.

$$
\mathrm{O}_{1} \rightarrow \mathrm{X} \rightarrow \mathrm{O}_{2}
$$

\section{HASIL DAN PEMBAHASAN PENELITIAN}

Penelitian ini dilakukan dalam model Analysis, Design, Development, Implementation dan Evaluation. Tahap analisis meliputi analisis awal, peserta didik, tugas, konsep, dan tujuan pembelajaran. Analisis awal terdiri dari analisis kurikulum yang berlaku dan sesuai dengan kompetensi dasar materi. Analisis awal bertujuan untuk mendapatkan informasi permasalahan dasar yang terjadi dalam pembelajaran mata pelajaran ekonomi di SMA Negeri 2 Kota Mojokerto. Saat ini pembelajaran tidak dilakukan tatap muka langsung disebabkan adanya pandemi. Dengan kondisi tersebut adanya perubahan kondisi pembelajaran yang dilakukan 
4367 Pengembangan Media Pembelajaran Word Search Puzzle Berbasis Android pada Mata Pelajaran Ekonomi Kelas X pada Saat Pandemi Covid-19 - Pandu Wahyu Gelang Pamungkas, Muhammad Abdul Ghofur DOI: https://doi.org/10.31004/edukatif.v3i6.1464

dimana guru melakukan tatap muka melalui zoom maupun googleclasrom. Adapun pembelajaran juga masih didukung dengan buku yang wajib dimiliki oleh siswa.

Ditengah kondisi pandemic saat ini banyak bermunculan game-game online yang dapat dapat memiliki berbagai pilihan. Banyaknya siswa yang bermain game dapat diinisiasi melakukan pengembangan pembelajaran yang menarik dan meningkatkan daya ingat siswa. Hal ini tentunya berdampak pada hasil belajar. Kompetensi Dasar (3.6) materi bank sentral, sistem pembayaran dan alat pembayaran, dimana pada materi tersebut perlu adanya mengingat materi, serta banyak waktu untuk mempelajari materi yang bertahap dan perlu adanya pengulangan. Dengan adanya permasalahan tersebut perlu adanya media pembelajaran yang dapat mengatasi permasalahan berkaitan dengan daya ingat siswa. Pada tahap analisis awal dapat dijadikan bahan pertimbangan untuk mengatasi permasalahan tersebut.

Analisis peserta didik dilakukan untuk mengetahui karakteristik setiap peserta didik pada kelas X IPS di SMA Negeri 2 Kota Mojoketo. Saat pembelajaran guru memberi materi yang ada di RPP dan selanjutnya peserta didik diberi tugas lalu mengumpulkan pada google classroom dan apabila ada tugas persentasi maka dilakukan melalui zoom. Saat pembelajaran banyak peserta didik yang masih susah dalam mengingat materi yang diajarkan guru, dan berdampak pada hasil belajar yang diraih. Oleh sebab itu, peneliti mengembangakan produk media belajar berbasis android dimana bisa diunduh di smartphone setiap peserta didik. Dimana didalam aplikasi terdapat fitur sumber belajar,dan bank soal yang akan mempermudah peserta didik untuk mengingat materi yang diajarkan. Produk yang dikembangkan bertujuan membuat peserta didik mampu belajar dengan lebih mudah dan memperkuat ingatan pada materi yang diberikan guru.

Analisis tugas merupakan bagian dari prosedur dalam merancang isi pembalajaran dengan rincian tugas, isi tugas, dan materi ajar yang akan dimaksukkan pada isi produk media pembalajaran yang dikembangkan. Materi yang tersedia disesuaikan dengan Rencana Pelaksanaan Pembelajaran (RPP). Materi yang dikembangkan pada media pembelajaran adalah bank sentral, sistem pembayaran dan alat pembayaran. Analisis tugas dilaksanakan dengan menyesuaikan materi pokok yaitu bank sentral, sistem pembayaran dan alat pembayaran. Pada tahap ini juga menyusun soal evaluasi berupa jawaban yang nantinya akan dikemas dengan sedemikian rupa dalam media pembelajaran yang akan dikembangkan untuk mengukur tingkat kemampuan mengingat materi dari peserta didik. Analisis konsep yakni sebuah tahapan melakukan analisis pada materi yang akan diberikan pada proses pembelajaran. Pada tahapan ini berupa peta konsep yang menjelaskan materi bank sentral, sistem pembayaran dan alat pembayaran. Dalam penyusunan tujuan pembelajaran dilaksanakan menggabungkan tujuan dari analisis materi dan analisis tugas menjadi acuan kompetensi dasar yang dilihat dari tingkah laku. Pada perencanaan tujuan pembelajaran berdasarkan Kompetensi Dasar (KD) dan indikator yang terdapat pada kurikulum 2013.

Tahap kedua yakni desain meliputi pemilihan media dan pemilihan format. Pemilihan media akan disesuaikan dengan hasil analisis materi dan disesuikan dengan karakteristik siswa saat pembelajaran. Dimana banyak peserta didik yang masih susah untuk mengingat materi yang diajarkan oleh guru dan pengulangan berupa ujian yang dilakukan peserta didik belum mendapatkan hasil yang maksimal. Adapun keberhasilan empiris yang didapatkan dari media pembelajaran yang diberikan guru yakni mencapai standar kompetensi minimum, akan tetapi belum mendapatkan nilai yang memuaskan untuk keseluruhan peserta. Oleh karena itu dibutuhkan media pembelajaran yang inovatif. Media yang akan digunakan pada penelitian ini yakni media pembelajaran puzzle berbasis android pada mata pelajaran bank sentral, sistem pembayaran dan alat pembayaran.

Pengembangan media pembelajaran puzzle berbasis android akan di desain semenarik mungkin agar bisa meningkatkan daya ingat dan juga memori siswa dalam jangka panjang. Menurut Anshorullah, (2008) Penerapan media pembelajaran inovatif dapat meningkatkan daya ingat siswa dalam mempermudah proses penyimpanan informasi materi belajar ke memori jangka panjang. Adapun kelemahan dari pembelajaran berbasis puzzle yakni tidak bisa menjawab pertanyaan dengan penjelasan jawabannya. Pemilihan media 
sangat strategis berkaitan dengan proses belajar yang efisien dan efektif terutama mengingat materi yang telah diberikan oleh guru.

Sedangkan pemilihan dari format media bertujuan merencanakan isi dari media pembelajaran yang disesuaikan dengan kurikulum 2013. Pengembangan media pembelajaran interktif akan dikembangkan berisi kompetensi dasar yang digunakan oleh sekolah, materi pembelajaran, latihan soal untuk melihat pemahaman materi, profil dan bantuan dimana akan dirancang semenarik mungkin supaya dapat meningkatkan daya ingat siswa mengingat sebuah materi yang diberikan guru.

Tahap ketiga yakni development meliputi menu yang terdapat pada permainan puzzle baik dari cover sampai dengan berakhirnya permainan. Menu awal menampilkan bentuk animasi permainan edukasi puzzle yang berisikan materi pelajaran bank sentral, sistem pembayaran dan alat pembayaran. Pada bagian ini merupakan langkah awal mengajak peserta didik belajar menyenangkan yang dikemas dalam tampilan berwarna dan menarik. Tampilan tersebut dibuat dengan menarik seolah sedang menggambarkan tentang permainan puzzle yang akan dimainkan oleh peserta didik. Pemilihan huruf dalam tampilan mengajak seseorang mengingat kata yang akan terdapat dalam permainan ini.

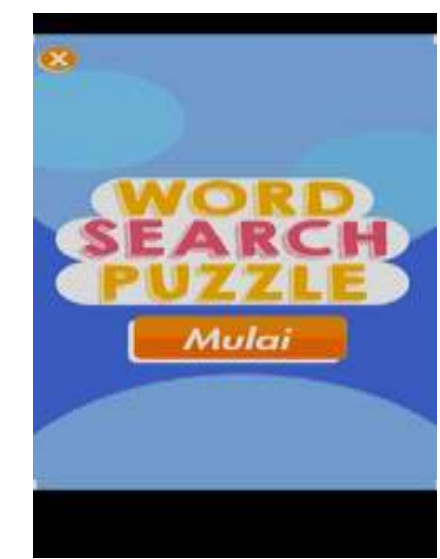

Gambar 1: Menu Awal Puzzle

Pada bagian halaman menu utama adalah halaman yang tampilkan setelah menekan tombol mulai pada bagian halaman pengantar. Halaman menu utama menampilkan menu materi, pengembang, kompetensi dasar, dan puzzle. Pada bagian menu materi menampilkan bab yang terdapat didalam permainan yakni bank sentral,alat pembayaran dan sistem pembayaran. Menu pengembang berisi tentang profil penulis. Pada menu puzzle terdapat Instruksi berisi mengenai cara bermain permainan puzzle. Menu KD berisi tentang tujuan pembelajaran dan indikator dalam setiap materi bank sentral,alat pembayaran dan sistem pembayaran. Sedangkan menu puzzle berisi level-level dalam permainan puzzle yaitu Bank sentral, Alat pembayaran, Sistem pembayaran.

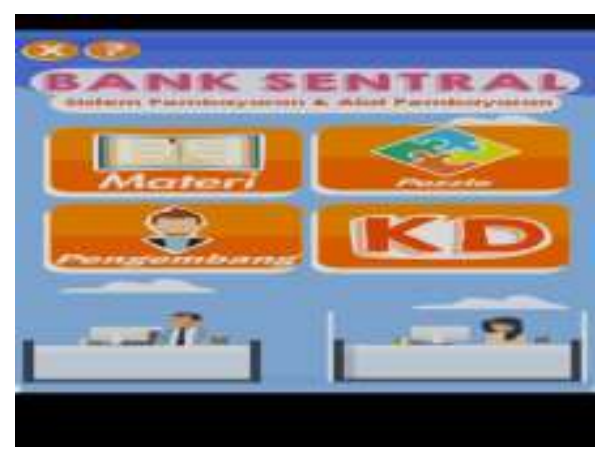

Gambar 2: Menu Utama 
Halaman menu materi berisikan pilihan level untuk permainan puzzle. Tingkatan level permainan puzzle disajikan pada soal Bank sentral untuk bahasan ke-1, alat pembayaran untuk bahasan ke-2, Sistem pembayaran untuk bahasan ke-3, serta gabungan materi untuk menu puzzle. Pada menu puzzle terdapat menu $\mathrm{KD}$, materi, dan menu main. Hal ini agar siswa dapat mengetahui tujuan pembelajaran yang dilakukan dan mencapai Kompetensi Dasar tentang Bank Sentral, Alat pembayaran dan Sistem pembayaran. Berikut ini adalah gambaran bahasan yang terdapat pada Bank sentral, alat pembayaran dan sistem pembayaran:

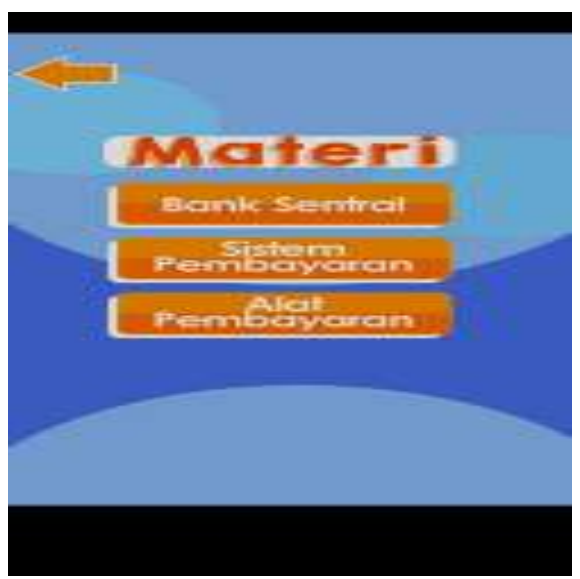

Gambar 3: Menu Materi

Pada halaman main pada setiap level berbeda tingkatannya, setiap level terdiri dari 3 soal, dimana tiap soal peserta didik diberi waktu untuk menjawabnya. Pada setiap level berbeda tingkat kesulitannya dimana pada level 1 disediakan soal dan jawaban yang benar. Level 1 berisikan soal dengan tipe $\mathrm{C} 1$ (pengetahuan), level 2 berisi soal C3 (pemahaman), level 3 berisi tentang soal C3 (analisis). Pada level 1 terdapat soal yang akan kembali muncul pada level berikutnya di level 3. Pada menu main terdapat bahasan pengulangan sebagian soal yang terdapat pada bahasan materi, serta terdapat pengulangan soal pada level berikutnya. Misalnya soal tentang bank sentral yang muncul pada pembahasan materi akan muncul pada menu main level 1 akan muncul kembali pada level 3. Pengulangan tersebut berdasarkan temuan hasil analisis dan observasi lapang bahwa peserta didik kesulitan dalam mengingat materi yang diberikan guru.

Menurut Roediger dan Karpicke menerangkan perlu ada tiga tahapan pengulangan tes. Pengulangan soal akan meningkatkan memory jangka panjang dan meningkatkan hasil belajar siswa (Roediger \& Karpicke, 2006). Pengulangan soal yang terdapat pada bahasan, serta yang terdapat pada menu main di level memiliki tujuan untuk melatih daya ingat dari peserta didik, selain itu bertujuan peningkatan hasil belajar. Pengulangan soal ini bertujuan sebagai meningkatkan recall memory peserta didik sehingga dapat menyimpan dalam memori jangka panjang. Berikut ini gambaran menu main. Hal ini untuk melatih daya ingat peserta didik
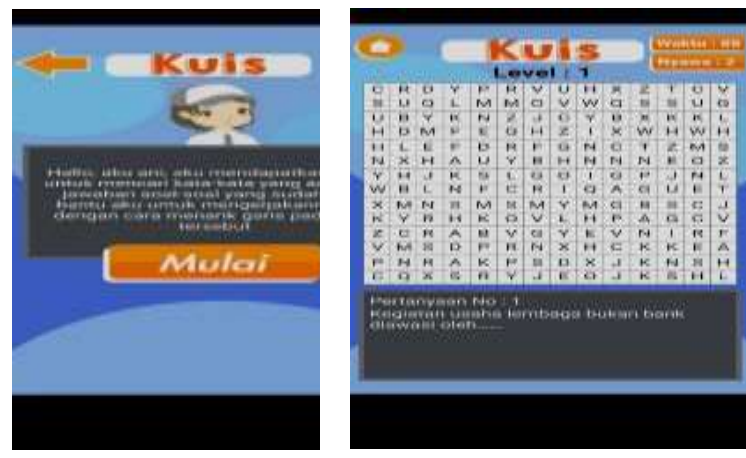

Gambar 4: Menu Puzzle 
Pada halaman ini berisi nilai yang diperoleh peserta didik selama permain. Semakin tinggi skor yang didapatkan menunjukkan tingginya daya ingat siswa, dikarenakan terdapat pengulangan materi soal yang dibahas. Selain itu pada halaman ini berisi kemenangan jika peserta didik berhasil meraih skor di atas kkm, waktu yang digunakan dalam permainan, nilai yang didapatkan. Hal ini menunjukkan kemampuan siswa dalam mencapai keberhasilan hasil belajar dan memenuhi kompetensi dasar pada materi yang dipelajarinya. Selain hal tersebut berisi ada tombol anak panah. Tombol ini akan menampilkan halaman awal dari Permainan puzzle ini.

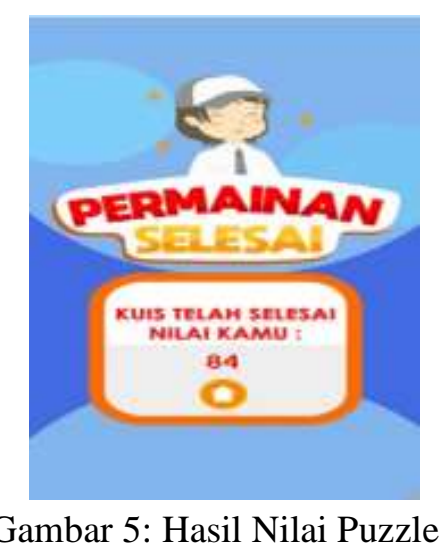

Dalam mengukur kemampuan siswa dalam mengingat materi dengan menggunakan game puzzle, dapat melakukan pengujian instrumen pada soal pretest dan posttest yang tersedia. Soal yang akan diberikan kepada siswa, akan terlebih dahulu uji validitas dan reliabilitas. Jumlah soal sebanyak 85 dengan jawaban pilihan ganda, yang terdiri dari 17 indikator. Hasil uji validitas dan reliabilitas dapat dilihat pada tabel 1 dibawah ini.

Tabel 1: Uji Validitas

\begin{tabular}{|l|c|}
\hline \multicolumn{1}{|c|}{ Number } & Keterangan \\
\hline $1,2,4,5,7,8,9,10,11,12,13,14,16,17,18,20,21,22,25,26,27,28,31,32,35,37,3$ & \\
$8,39,41,42,43,44,45,46,48,50,51,52,53,54,56,57,59,60,62,63,64,65,67,68$, & Valid \\
$69,71,72,73,76,78,79,82,84,85$ & \\
\hline $3,6,15,19,23,24,29,30,33,34,36,40,47,49,55,58,61,66,70,74,75,77,80,81,83$ & Tidak Valid \\
\hline
\end{tabular}

Sumber : Data diolah (2021)

Berdasarkan data diatas untuk seluruh instrument penelitian sudah valid dikarenakan telah memenuhi nilai Pearson Correlation $>0,3$ sesuai dengan yang dinyatakan oleh Sugiyono (2014:126) sehingga instrument tersebut dapat digunakan untuk penelitian selanjutnya.

Tabel 2. Uji Reliabilitas

\begin{tabular}{c}
$\frac{\text { Reliability Statistics }}{\text { Cronbach's Alpha }}$ \\
\hline N of Items \\
\hline Sumber : Data diolah (2021)
\end{tabular}

Berdasarkan data diatas hasil uji reliabilitas. Dapat dilihat untuk nilai Cronbach's Alpha sebesar 0.987. Jadi dapat dikatakan instrumen yang digunakan reliabel dan dapat digunakan dalam penelitian selanjutnya. 
Berdasarkan data yang didapatkan sebanyak 36 siswa terdiri dari 12 responden berjenis kelamin pria atau sebesar 44,4\% dari total siswa Sedangkan responden dari jenis kelamin perempuan sebesar 24 responden atau sebesar \% dari total responden. Berdasarkan data penelitian dapat diketahui hasil dari pretest dan posttest. Nilai rata-rata pretest dari 36 siswa sebesar 80.00, sedangkan nilai post test sebesar 88,44. Hal ini dimaknai adanya pengaruh signifikan peningkatan hasil belajar siswa dengan menggunakan media pembelajaran puzzle.

Tabel 3. Uji Normalitas

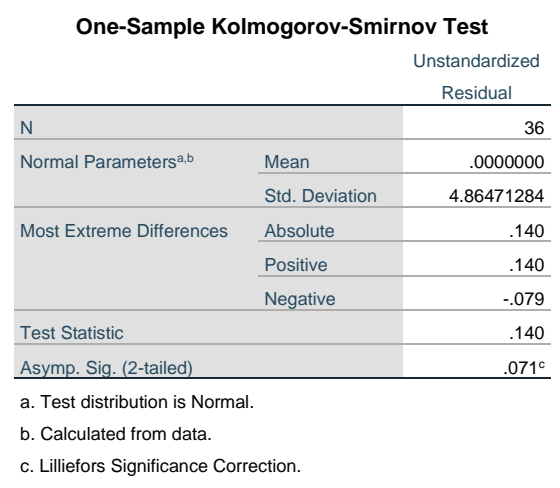

Sumber : Data diolah (2021)

Berdasarkan data diatas, menunjukkan hasil uji normalitas dan dapat diketahui bahwa data memiliki signifikan 0.071 dengan telah memenuhi kategori bahwa a > 0.05, sehingga dapat disimpulkan bahwa hasil pretest dan posttest dalam kategori tersebut berdistribusi normal.

Tabel 4. Uji T

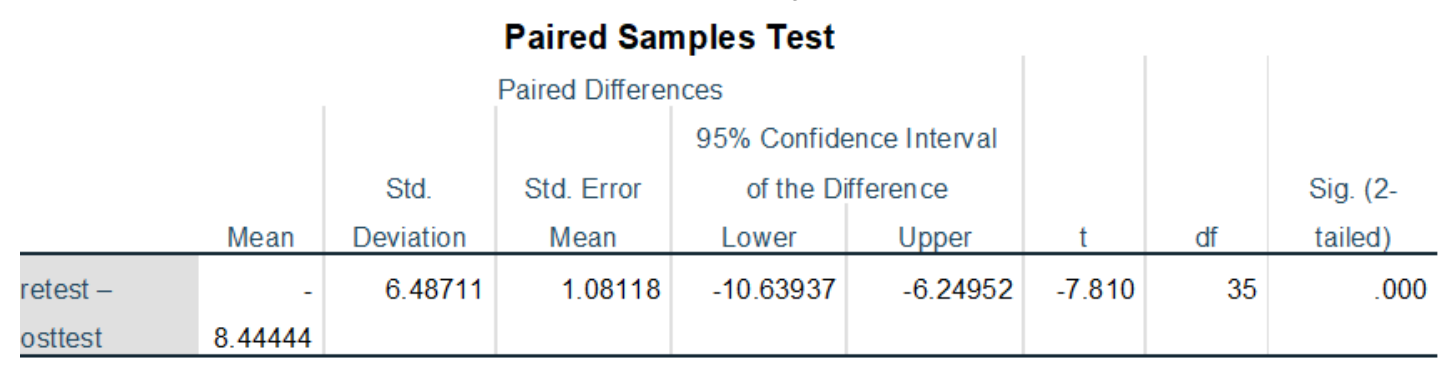

Sumber data diolah (2021)

Berikutnya yakni dengan melihat hasil uji t, dengan syarat melakukan uji t pada uji normalitas menggunakan Kolmogorov Smirnov yakni suatu data wajib terdistribusi normal. Uji t untuk melihat apakah terdapat perbedaan hasil pretest dan posttest untuk penggunaan media pembelajaran puzzle. Jika nilai sig < 0.05, maka terdapat perbedaan hasil pretest dan posttest, namun apabila nilai sig $>0.05$, maka dapat disimpulkan data tersebut tidak menunjukkan adanya perbedaan hasil post test dan pre test.

Berdasarkan tabel diatas, dimana hasil pretest dan post test adalah sig. (2-tailed) sebesar 0.00 lebih kecil dari 0.05. Hal ini menunjukkan $\mathrm{H} 0$ ditolak dan dapat menerima H1, yang artinya bahwa hasil data baik pada hasil pembelajaran menggunakan pretest dan post test dengan media pembelajaran puzzle. Peningkatan hasil belajar dan daya ingat menggunakan media pembelajaran puzzle berbasis android dengan metode pengembangan ADDIE dibandingkan dengan menggunakan metode konvesional dalam meningkatkan materi yang diingat oleh siswa. 
Selain itu penelitian yang menggunakan media pembelajaran puzzle sangat efektif dan cocok untuk proses pembelajaran dalam meningkatkan materi yang diingat oleh siswa. Penelitian yang dilakukan Mujaiyanah, (2020) menunjukkan pengaruh signifikan dalam hal peningkatan hasil belajar siswa. Hal ini disebabkan pembelajaran dikemas menarik dalam suatu game puzzle. Selain itu, dapat meningkatkan materi yang diingat oleh siswa pada materi yang diajarkan guru. Perbedaan penelitian dengan sebelumnya terletak pada subjek dan mata pelajaran.

Pada observasi dilapangan terjadi peningkatan materi yang diingat dalam pembelajaran yang dilakukan. Pada penelitian ini pembelajaran tetap didampingi oleh guru mata pelajaran yakni Ibu Tri Winarsih. Guru menjelaskan gambaran materi yang diajarkan,selain itu memberi stimulus pada siswa yang mendapatkan nilai 3 terbaik untuk diberikan tambahan poin. Hal ini membuat siswa konsentrasi dalam mengikuti kelas. Pembelajaran menggunakan puzzle dalam jangka panjang dapat meningkatkan materi yang diingat siswa yang diberikan guru.

Tahap keempat yaitu Implementation, pada tahap ini link pretest, link game puzzle dan link posttest disebarkan melalui group whatsapp peserta didik. Selain itu peserta didik dapat mempelajari materi yang tersedia di dalam game puzzle. Untuk hasil yang diperoleh pada game puzzle peserta didik diwajibkan screenshot hasil dan dikirimkan kepada peneliti.

Tahap kelima yakni evaluasi dimana siswa diberikan kuisioner untuk menilai hasil proses yang telah dilakukan. Penyebaran kuisioner ini melalui google form yang dikirim melalui group kelas peserta didik. Kuisioner ini dapat melihat respons mengingat materi siswa dalam proses pembelajaran, untuk mengetahui kebaikan dan kekurangan yang dapat diperbaiki pada proses pembelajaran menggunakan puzzle. Pada hasil ini kuisoner yang telah diberikan bahwa siswa merasa pembelajaran berdampak positif pada peningkatan daya ingat untuk mengingat materi yang telah diajarkan oleh guru.

Berdasarkan uraian data yang diperoleh dapat dikatakan bahwa peneliti berhasil menerapkan model pembelajaran ADDIE dengan media puzzle pada mata pelajaran ekonomi, dimana media pembelajaran dikemas semenarik mungkin dan membuat siswa lebih mudah mengingat materi yang diberikan guru. Kriteria keberhasilan ini dapat dilihat pada hasil pretest dan posttest, dimana penggunaan media pembelajaran puzzle siswa dapat meningkatkan daya ingat siswa dalam mengingat materi yang diberikan guru.

Berdasarkan hasil penelitian dapat disimpulkan bahwa penggunaan puzzle sebagai media pembelajaran berpengaruh positif terhadap daya ingat siswa dan dapat meningkatkan hasil belajar pada mata pelajaran ekonomi kelas X SMA Negeri 2 Kota Mojokerto.

\section{KESIMPULAN}

Berdasarkan penelitian yang telah dilaksanankan di SMA Negeri 2 Kota Mojokerto dapat disimpulkan sebagai berikut 1) terdapat pengaruh positif pembelajaran puzzle terhadap daya ingat siswa, 2) terdapat pengaruh positif pembelajaran puzzle terhadap hasil belajar. Keefektifan media pembelajaran menggunakan puzzle ini dilihat berdasarkan hasil belajar siswa melalui uji pre-test dan post-test dan menggunakan analisis ttest. Berdasarkan hasil penelitian t-test diperoleh bahwa adanya peningkatan hasil belajar siswa. Hal ini dapat disimpulkan untuk media pembelajaran menggunakan puzzle layak digunakan untuk meningkatkan mengingat materi yang diberikan oleh guru dan dapat meningkatkan hasil belajar siswa.

\section{DAFTAR PUSTAKA}

Anshorullah, R. (2008). Efektivitas Strategi Mnemonic Dalam Meningkatkan Daya Ingat Siswa Pada Mata Pelajaran Sejarah Di Mts Persiapan Negeri Kota Batu. Universitas Islam Negeri Malang.

Azhar, A. (2013). Media Pembelajaran. Jakarta: PT Raja Grafindo Persada. 
4373 Pengembangan Media Pembelajaran Word Search Puzzle Berbasis Android pada Mata Pelajaran Ekonomi Kelas X pada Saat Pandemi Covid-19 - Pandu Wahyu Gelang Pamungkas, Muhammad Abdul Ghofur DOI: https://doi.org/10.31004/edukatif.v3i6.1464

Bahri, D. S. (2002). Strategi Belajar Mengajar. Jakarta: PT. Rineka Cipta.

Darmayanti. (2016). Penggunaan Media Virtual Interaktif Untuk Meningkatkan Hasil Belajar Siswa Pada Konsep Tekanan Di Kelas X SMK Negeri 5 Telkom Banda Aceh (UIN Ar-Raniry) (UIN AR-RANIRY). Retrieved From Http://Dx.Doi.Org/10.1016/J.Carbpol.2016.12.050\%0Ahttp://Dx.Doi.Org/10.1016/J.Indcrop.2016.04.06 4\%0Ahttp://Dx.Doi.Org/10.1016/J.Carbpol.2016.05.028\%0Ahttp://Xlink.Rsc.Org/?DOI=C6NR09494E \%0Ahttp://Dx.Doi.Org/10.1016/J.Carbpol.2014.12.064\%0Ahttp://Dx.Doi.Org/10.1016/

Desmita. (2009). Psikologi Perkembangan Peserta Didik. Bandung: Remaja Rosdakarya.

Hidayah, L. Fatihatul. (2014). Penerapan Game Puzzle Untuk Meningkatkan Daya Ingat/Memori Siswa Pada Mata Pelajaran Sejarah Kelas XI IPA Di MAN Kota Kediri 3. UIN Malang.

Ivana Rahman. (2011). Upaya Mengurangi Dampak Stigmatisasi Narapidana Kasus Perkosaan Terhadap Keluarganya. Universitas Indonesia.

Kurniawan, A., Satoto, K. I., \& Kridalukmana, R. (2015). Perancangan Dan Pengembangan Permainan Jelajah Indonesia Berbasis Ios Menggunakan Gamesalad. 3(1), 26-35.

Luhsasi, D. I., \& Sadjiarto, A. (2017). Youtube: Trobosan Media Pembelajaran Ekonomi Bagi Mahasiswa. Jurnal Ekonomi Pendidikan Dan Kewirausahaan, 5(2), 219. Https://Doi.Org/10.26740/Jepk.V5n2.P219229

Mujaiyanah, S. (2020). Mengukur Hasil Belajar Ekonomi Menggunakan Media Asesmen Word Search Puzzle Di Platform Android. Edunomic Jurnal Pendidikan Ekonomi, 8(2), 107. Https://Doi.Org/10.33603/Ejpe.V8i2.3669

Nurhalifah, Lestari, N., \& Yusuf, M. (2020). Jurnal Biosains Dan Edukasi Efektifitas Media Pembelajaran Word Search Puzzle Dalam Meningkatkan Daya Ingat Siswa Pada Materi Ekosistem Kelas VII Di SMP Muhammadiyah Kupang Tahun Ajaran 2018 / 2019. Jurnal Biosains Dan Edukasi, 2(1), 17-23.

Raharjo, S. B. (2010). Metodelogi Penelitian Kualitatfi. Jurnal Pendidikan Dan Kebudayaan, 16, 229-238.

Ratnaningsih, T. (2010). Pengguanaa Evaluasi Word Search Puzzle Untuk Meningkatkan Kekayaan Kosa Kata Biologi Siswa Pada Pokok Bahasan Zat Additif Dan Psikotropika Kelas Viii Smp Negeri 7 Surakarta Tahun Pelajaran 2008/2009. Universitas Sebelas Maret.

Roediger, H. L., \& Karpicke, J. D. (2006). Test-Enhanced Learning: Taking Memory Tests Improves LongTerm Retention. Psychological Science, 17(3), 249-255. Https://Doi.Org/10.1111/J.14679280.2006.01693.X

Sani, R. A. (2018). Penelitian Pendidikan. Tangerang: Tara Smart.

Solso, R. L., Maclin, O. H., \& Maclin, M. I. (2008). Psikologi Kognitif. (Edisi Kede). Jakarta: Erlangga.

Sudjana, N. (1999). Penelitian Hasil Proses Belajar Mengajar. Bandung: Remaja Rosdakarya.

Sugiyono. (2017). Metode Penelitian Kuantitatif, Kualitatif, Dan R\&D. Bandung: CV. Alfabeta.

Vitianingsih, A. V. (2016). Game Edukasi Sebagai Media Pembelajaran Pendidikan Anak Usia Dini. 1(1), 18.

Wahyuni H, S. (2018). Pengembangan Media Pembelajaran Word Search Puzzle Pada Kelas X Iis Sma Negeri 16 Surabaya Tahun Pelajaran 2017/2018. Jurnal Pendidikan Ekonomi (JUPE), 6(3), 336-342. Https://Doi.Org/10.26740/Jupe.V6n3.P

Walgito, B. (2004). Pengantar Psikologi Umum. Jakarta: Penerbit Andi. 